\title{
USE OF THE BENCHMARK DOSE APPROACH FOR EVALUATION OF DOSE AND TIME-DEPENDENT RESPONSE TO 7-HYDROXYCOUMARIN 90-DAY EXPOSURE IN RAT FEMALES
}

\author{
M.L. Zinovieva, P.G. Zhminko, M.G. Prodanchuk \\ L.I.Medved's Research Center of Preventive Toxicology, Food and Chemical Safety, \\ Ministry of Health of Ukraine, Kyiv, Ukraine
}

ABSTRACT. Benchmark dose (BMD) analysis of existing data sets from experimental studies on animal for which NOAEL/LOAEL information is available allows to satisfy the need for quantifiable, scientifically justifiable approach to risk assessment. Previous study of 7-hydroxycoumarin (7-HOC) 3 months toxicity on rats revealed carbohydrates and lipids metabolism disturbance (blood glucose level (BGL) decrease, serum triglyceride level (STL) rise) as biologically relevant parameters to set up NOEL (20 mg/ $\mathrm{kg})$.

Purpose. To conduct the dose and time of exposure effect dependence comparative analysis of BGL and STL published data set of 7HOC subchronic toxicity in rats using BMD and NOAEL/LOAEL methodologies.

Materials and methods. The available continuous data of STL and BGL from subchronic 7-HOC toxicity study data set for rat females were analyzed by means United States Environmental Protection Agency proposed software, BMDS 2.6.0.1. The response level was set as $10 \%$.

Results. Hill's model appropriately reflected BGL and STL dependence on 7-HOC dose. The BMDs estimates of STL rise were similar $(46-49 \mathrm{mg} / \mathrm{kg})$ in 1, 2, and 3 months of exposure. Coincident dependence was found for the lower-bound confidence limits on the BMDs (BMDLs) ranged 21-22 $\mathrm{mg} / \mathrm{kg}$ at all the studied time points, whereas NOEL for this end point was defined as 50, 20, and $20 \mathrm{mg} / \mathrm{kg}$ in 1,2 , and 3 months respectively.

$B M D$ s of the BGL decrease were rising with time of exposure amounting 48, 93, $486 \mathrm{mg} / \mathrm{kg}$ after 1, 2, and 3 months respectively. BMDLs estimates were 24, 21, $207 \mathrm{mg} / \mathrm{kg}$ in 1, 2, and 3 months respectively, while NOEL for this end point were 50, 200, and 200 $\mathrm{mg} / \mathrm{kg}$ at correspond time points.

Conclusion. The benchmark dose method was more powerful statistical tool to analyze 7-HOC effects dose dependence in comparison to traditional approach. The observed BMDs and theirs derivatives changes indicated no enhancement of studied treatment related responses within the exposure time.

Key words: benchmark dose approach, 7-hydroxycoumarin, subchronic toxicity.

Introduction. The current paradigm of regulatory toxicology considers the No Observed Adverse Effect Level (NOAEL) and the Lowest Observed Adverse Effect Level (LOAEL) of a studied chemical substance as reliable initial points obtained from experimental animal data for determination of regulatory levels such as reference doses (RFDs) and acceptable daily intakes (ADIs). However the NOAEL/LOAEL approach not free from some shortcomings, elicited by Cramp in 1984 [1] and generalized later [2]. Specific limitations of the NOAEL/LOAEL approach includes its high dependence of a study design. In particular, the NOAEL value is limited to one of doses set up before the study. The value depends on sample size, because ability of a bio-test to distinguish an effect in compare to a control group decreases when a sample size decreases. As well as variability and uncertainty in the experimental results are not accounted when NOAEL/LOAEL approach is used. Moreover it is challenge to compare results across stud- ies because the approach does not account a level of response. In case when NOAEL in experimental study is not determined there is only one possibility to set it up for regulatory needs by use of formal uncertainty factor 10 [3]. In addition very little information is used of high dose effect. NOAEL/LOAEL approach utilizes preferably qualitative information, demonstrating weak use of the available data in a quantitative way. Thus the NOAEL is actually of little practical utility in describing toxicological dose-response relationship and demonstrates lack of possibilities to provide quantitative assessment of the biological process.

To overcome the mentioned shortcomings of NOAEL/LOAEL approach and to satisfy the need for transparent and scientifically justifiable approaches the benchmark dose (BMD) approach is proposed for threshold effects (non-genotoxic) as providing more quantitative way of dose-response relationship assessment. The BMD approach involves modeling the dose-response curve in the range 
of the observable data, and then using that model to interpolate an estimate of the dose that correspond to a particular level of response. Because the current risk assessment practice assumes that a threshold dose exists for effects other than oncogenicity (considered as non-threshold effect), and toxicologically significant effects are not likely to occur below the threshold dose, the response is set at a certain level as defined by risk assessor. The default benchmark response is at $5 \%$ change in the group mean relative to control, although it can be modified in accordance to the biological significance of the endpoint and other toxicological considerations $[4,5]$.

Conversely to the NOAEL/LOAEL approach, which allows determining the levels directly from the study, the BMD approach requires an extra step of fitting models to the dose-response data before determining effective dose at a specified response level and its lower bound within the predetermined confidence. Therefore BMD is defined as the dose causing the specified increase in the risk for adverse health effects. The lower $95 \%$ confidence limit on the BMD (BMDL) has been proposed to replace the NOAEL.

BMD approach provides new advantages for the dose-response assessment for threshold effects allowing to characterize the doseresponse curve by using all appropriate datapoints, to establishing the threshold dose with defined consistency, to account for uncertainties due to different sample size or variations in endpoints measurements/observations when the threshold dose is set up, and to estimate the threshold dose when no NOAEL can be established in the study. Being introduced more than 20 years ago, the BMD approach has not been widely used until recent time because of low accessibility of suitable mathematical models. The situation changed drastically from the moment of BMD software become publicly available. The easily available software facilitate harmonization of chemical risk assessment approaches, allows to provide deeper analysis of existing chemical safety data sets for which NOAEL/LOAEL approach had been used.

Evaluation of the existing data sets from experimental studies on animal for which NOAEL/LOAEL information is available using benchmark dose approach is aimed to satisfy the need for scientifically justifiable approach to risk assessment. Accordingly, we analyzed the dataset of previously studied 7hydroxycoumarin (7-HOC) 90-days oral toxicity in rat. 7-HOC is phytoconstituent found in eatable and officinal plants belonging to umbelliferae family. Besides, 7-HOC is the main, low toxic metabolite of coumarin in a human body [6]. A wide range of pharmacological activities of 7-HOC is demonstrated in animal studies. The compound lowers serum glucose level in rats with streptozotocin diabetes, exhibit antioxidant, antinociceptive and anti-inflammatory effects, is used as derivative in the synthesis of drugs [7-12]. Because the compound is proposed as potential food additive, its toxic properties were evaluated. In the conducted toxicological study in rat was found that 90-days oral exposure of 7-HOC at doses 20-50-200-500 mg/kg induced carbohydrates and lipids metabolism disturbance comprising blood glucose level (BGL) decrease, and serum triglyceride level (STL) rise observed at doses $50 \mathrm{mg} / \mathrm{kg}$ and higher [13]. These endpoints were considered as sensitive and biologically relevant treatment-related response that could be traced through the time of subchronic exposure. The NOAEL/LOAEL analysis established the lowest studied dose, $20 \mathrm{mg} / \mathrm{kg}$ as no observable effect level (NOEL). Because clinical chemistry changes are early indicator of biological or toxicological effect of a xenobiotic treatment, it is of interest to estimate BMDs and BMDLs for different time points of a repeat-dose toxicity study to analyze the response time variation with the purpose to assess development of biologically/toxicologically meaningful changes within the time of exposure.

Objectives. The current study was aimed to conduct dose and temporal effect dependence comparative analysis of BGL and STL from existing data set of 7-HOC subchronic toxicity in rats using BMD and NOAEL/LOAEL methodologies.

Materials and methods. The data set for 7HOC 90-days oral toxicity in rat females (5 per group) at doses $0,20,50,200,500 \mathrm{mg} / \mathrm{kg}$ was used [13]. BGL and STL registered in 1, 2, 3 months of 7-HOC exposure were chosen as pertinent endpoints to be analyzed with BMD approach. The summarized forms of continuous data of BGL decrease and STL rise were considered as appropriate for analysis by means of BMDS software due to number of 
dose levels for the data set, sample size, mean, and measure of variability (standard deviation (SD)) meet requirements of data criteria for BMD analysis [5]. Although default value $5 \%$ recommended for continuous experimental data risk level by guidelines [5] we set up the risk value $10 \%$ to derive BMD because the used end points are parameters with high variability [14].

Dose dependence analysis was done by means of BMDS 2.6.0.1 software. The most appropriate models for BGL decrease and STL rise were defined. BMDs, and BMDLs on a $10 \%$ response were estimated for $1,2,3$ months of 7 -HOC exposure:

Results and discussion. It was found that Hill's model appropriately reflects both STL rise and BGL decrease in dependence on 7HOC dose at all studied time points.

Summarized data on STL are laid out in Table 1. As it can be seen, in one month of exposure statistically significant changes are revealed at doses $200 \mathrm{mg} / \mathrm{kg}$ and higher, at later time points significant STL increase were found at dose levels $50 \mathrm{mg} / \mathrm{kg}$ and higher. Thus NOAEL for the STL rise was $50 \mathrm{mg} / \mathrm{kg}$ for 1 month of exposure and $20 \mathrm{mg} / \mathrm{kg}$ for 2 and 3 months. When the data was assessed using BMD-approach (Figure 1), no substantial changes of BMDs estimated within the time of exposure were found. The values obtained were 47,$7 ; 48,5$; and $45,7 \mathrm{mg} / \mathrm{kg}$ in 1,2 , and 3 months respectively. As well as the derived BMDLs were similar, 21,5; 20,5; 21,6 mg/kg after 1, 2, 3 months treatment respectively. Thus BMD modelling adequately reflects the NOAEL obtained for STL rise in the traditional NOAEL/LOAEL approach but demonstrated better sensitivity to detect early changes (in 1 month) of the studied clinical chemical parameter.

The data set of BGL decrease in course of 7-HOC repeat-dosing shown in Table 2. As the table shows, there were no statistically significant changes at two lowest studied doses (20, and $50 \mathrm{mg} / \mathrm{kg}$ ). At dose level $200 \mathrm{mg} / \mathrm{kg}$ the change occurred at early time point (1 month) of exposure only. At the high dose level significant BGL decline was found at all the studied time points. Consequently NOELs defined by BGL decease in 1, 2, 3 month were 50, 200, $200 \mathrm{mg} / \mathrm{kg}$ respectively.

When BMD approach was used to analyze the observed BGL changes (Figure 2) it was found BMDs gradually rising depending on time of exposure amounting 48, 93, $486 \mathrm{mg} / \mathrm{kg}$ at 1,2 , and 3 months respectively. At the same time, BMDLs calculated for BGL decrease was $24 \mathrm{mg} / \mathrm{kg}$ in $1 \mathrm{month}$, and $21 \mathrm{mg} / \mathrm{kg}$ in 2 months, but rising up to $207 \mathrm{mg} / \mathrm{kg}$ in 3

Serum triglycerides level data set $(M, S D, n=5)$

\begin{tabular}{|c|c|c|c|c|}
\hline \multirow{2}{*}{\multicolumn{2}{|c|}{ Dose, $\mathrm{mg} / \mathrm{kg}$}} & \multicolumn{3}{|c|}{ Time of exposure, month } \\
\hline & & \multirow{2}{*}{$\frac{\mathbf{1 m}}{0,83}$} & \multirow{2}{*}{$\frac{\mathbf{2 m}}{1,04}$} & \multirow{2}{*}{$\begin{array}{c}\mathbf{3 m} \\
1,02\end{array}$} \\
\hline . & M & & & \\
\hline 0 & $\mathrm{SD}$ & 0,157 & 0,134 & 0,156 \\
\hline \multirow{2}{*}{20} & M & 0,90 & 1,01 & 0,98 \\
\hline & SD & 0,403 & 0,201 & 0,179 \\
\hline \multirow{2}{*}{50} & $\mathrm{M}$ & 1,24 & $1,26^{*}$ & $1,46^{*}$ \\
\hline & SD & 0,515 & 0,112 & 0,268 \\
\hline \multirow{2}{*}{200} & $\mathrm{M}$ & $2,00 *$ & $1,37^{*}$ & $1,73^{*}$ \\
\hline & SD & 0,515 & 0,268 & 0,217 \\
\hline \multirow{2}{*}{500} & $\mathrm{M}$ & $1,96^{*}$ & $1,47^{*}$ & $1,80^{*}$ \\
\hline & SD & 0,180 & 0,246 & 0,110 \\
\hline
\end{tabular}

$*_{-} \mathrm{p}<0,05$ 


\section{1 month}

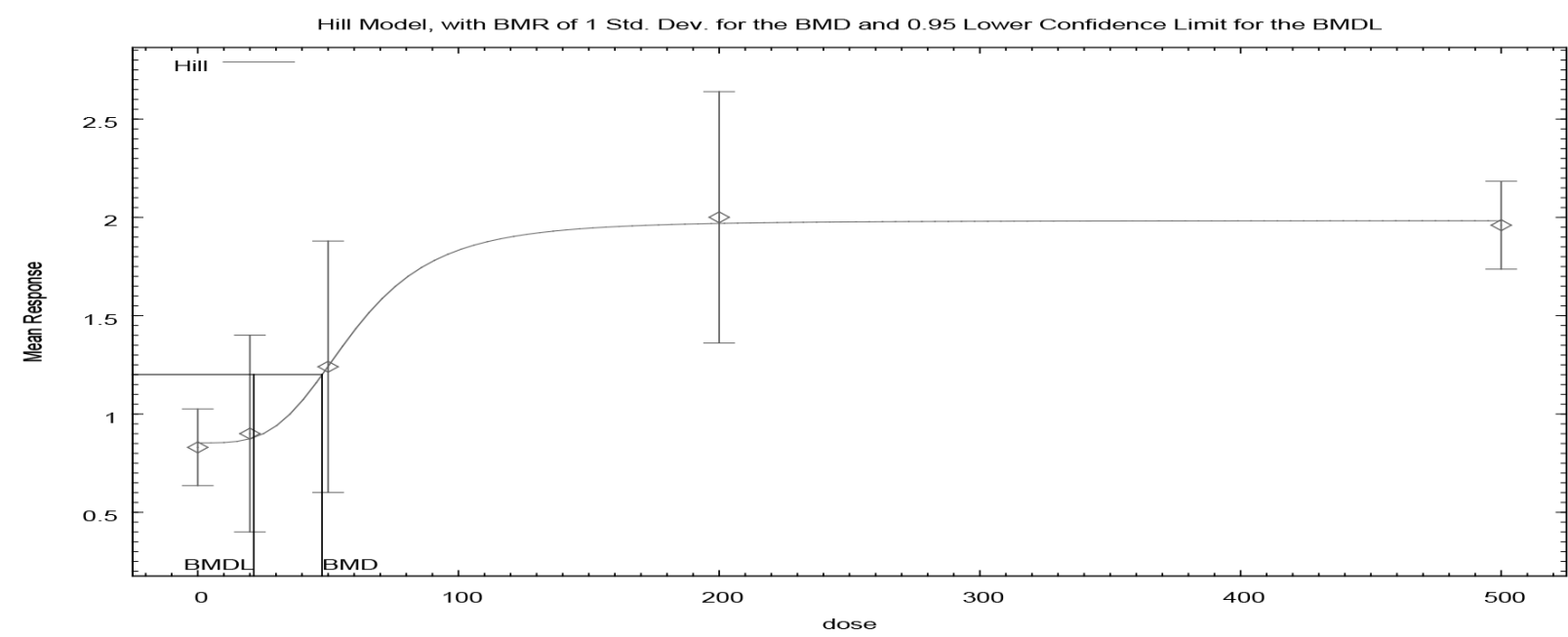

\section{2 months}

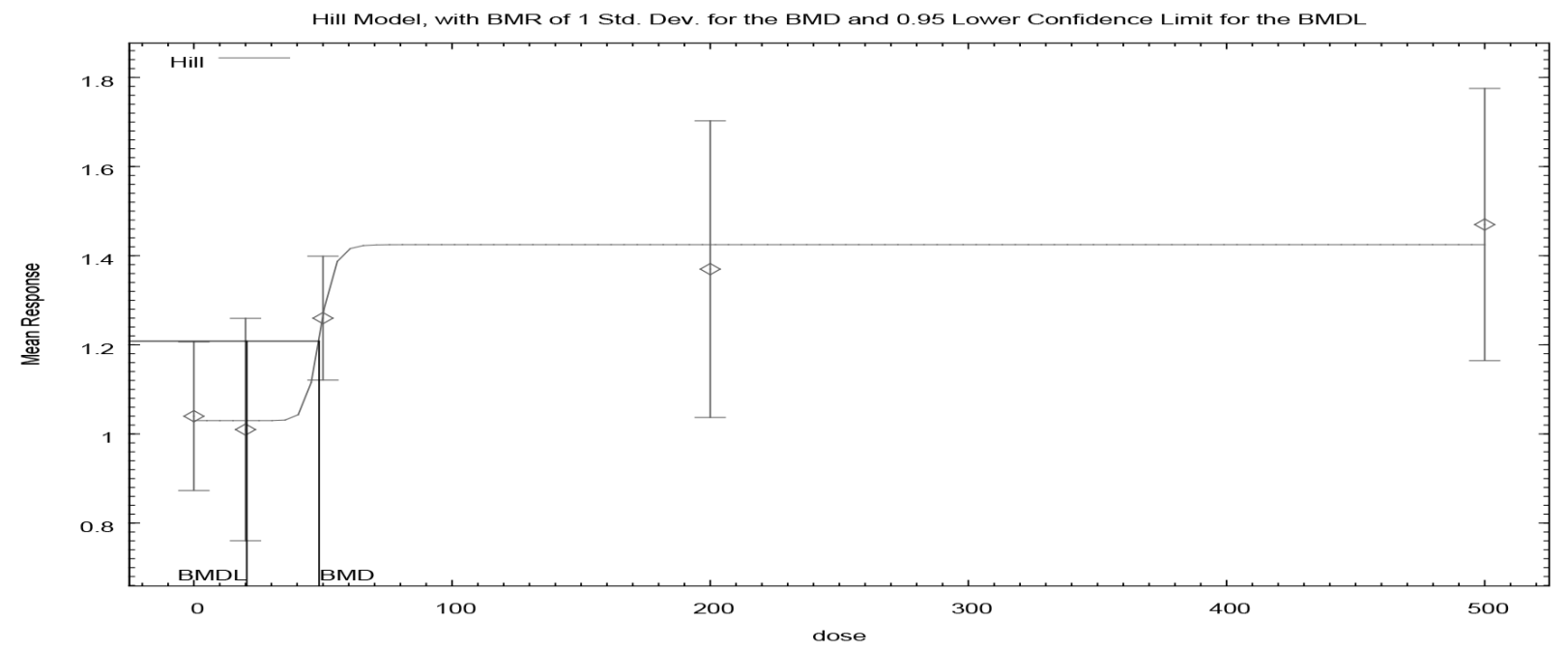

\section{3 months}

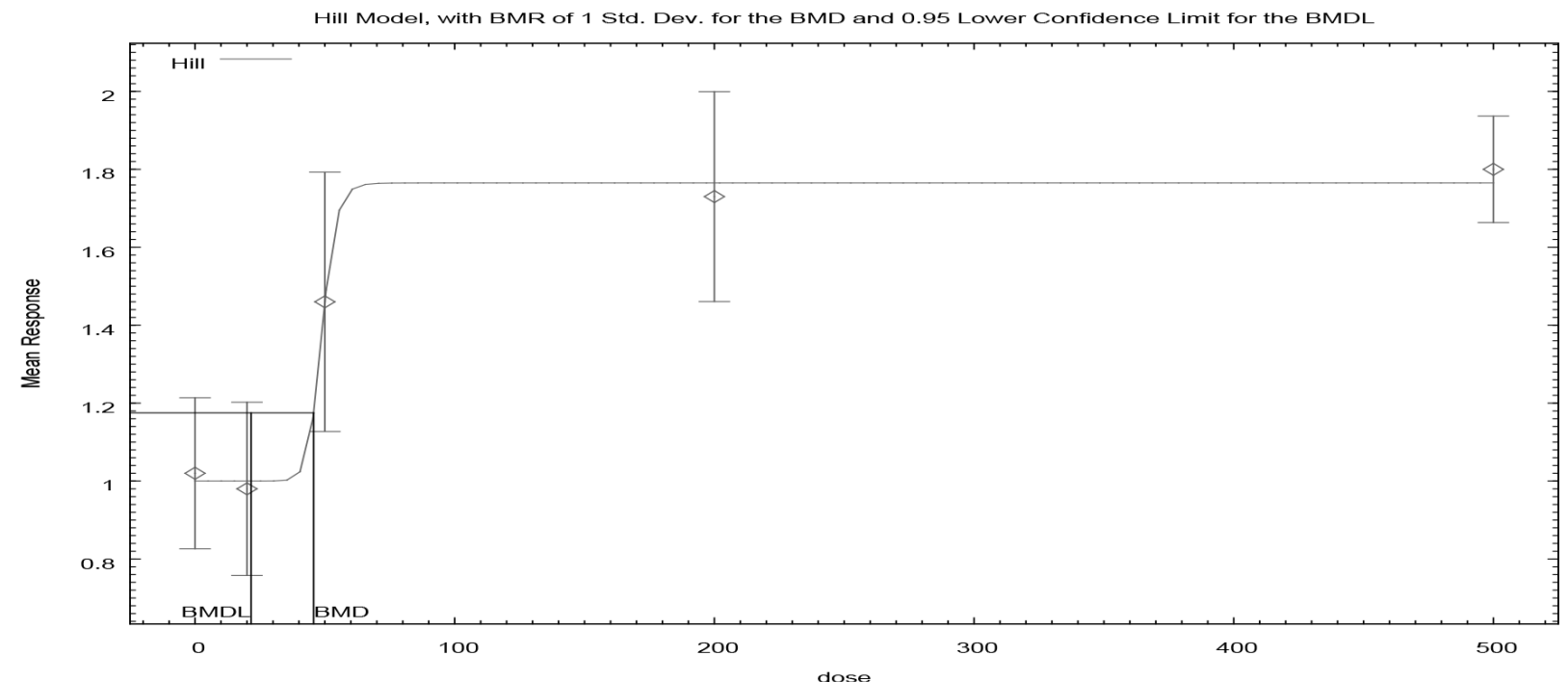

Figure 1. BMDS 2.6.0.1 modeling the dose dependence of serum triglycerides level in 1, 2, and 3 months exposure to 7-hydroxicoumarin 


\section{1 month}

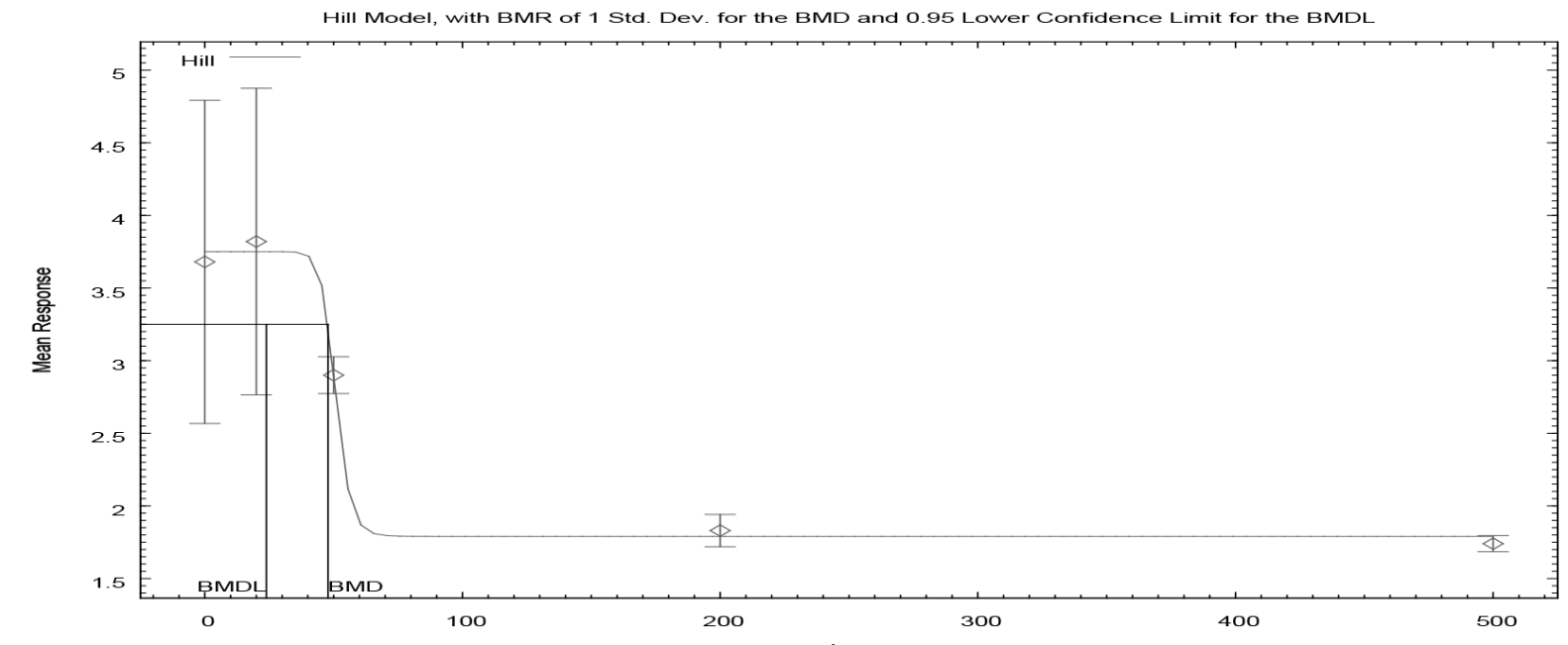

2 month
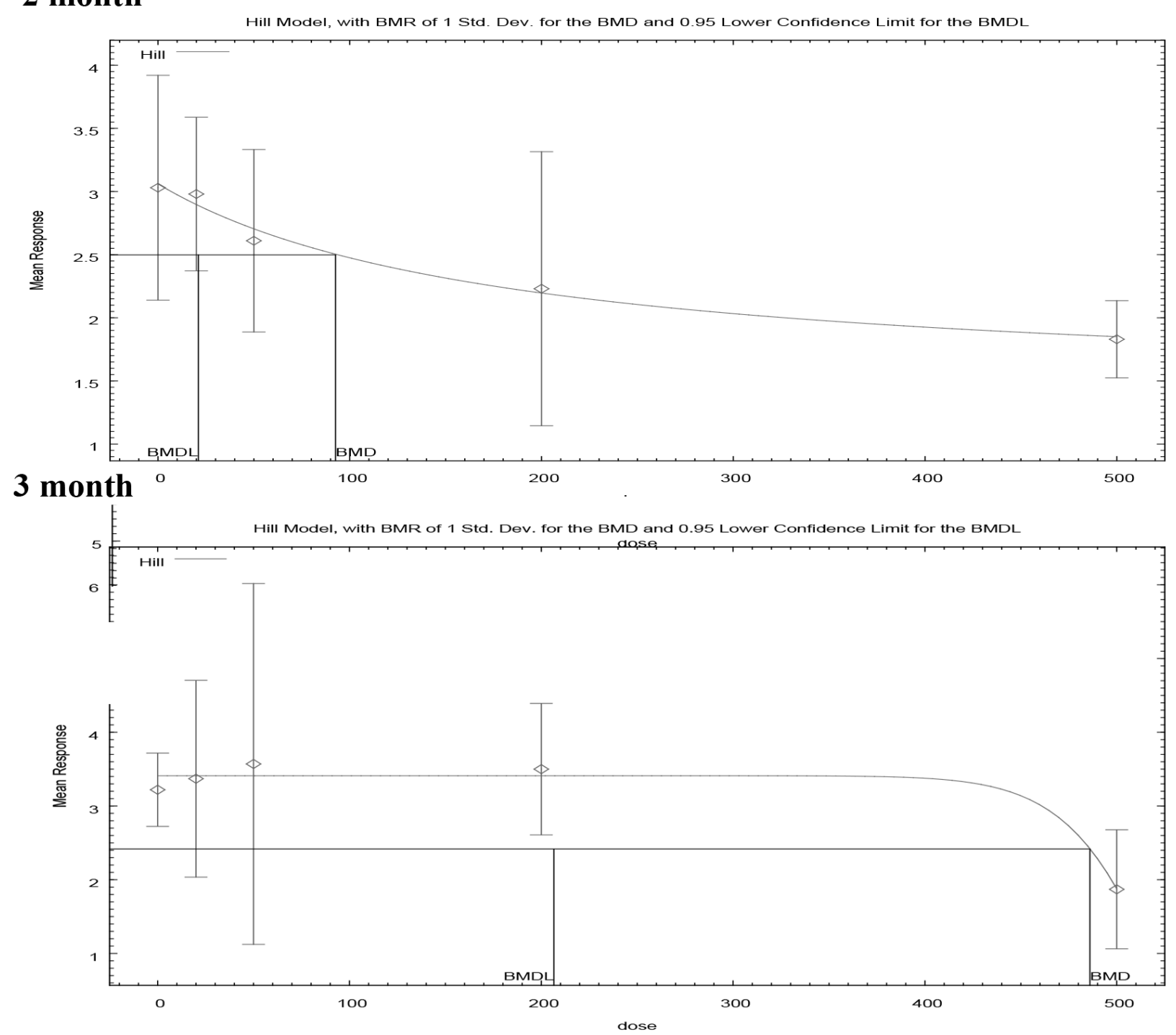

Figure 2. BMDS 2.6.0.1 modeling the dose dependence of blood glucose level in 1, 2, and 3 months exposure to 7-hydroxicoumarin 
Table 2

Blood glucose level data set $(M, S D, n=5)$

\begin{tabular}{|c|c|c|c|c|}
\hline \multirow{2}{*}{ Dose, $\mathbf{m g} / \mathbf{k g}$} & \multicolumn{3}{|c|}{ Time of exposure, month } \\
\cline { 2 - 5 } \multicolumn{2}{|c|}{} & $\mathbf{1}$ & $\mathbf{2}$ & $\mathbf{3}$ \\
\hline \multirow{2}{*}{0} & $\mathrm{M}$ & 3,68 & 3,03 & 3,22 \\
\cline { 2 - 5 } & $\mathrm{SD}$ & 0,896 & 0,717 & 0,400 \\
\hline \multirow{2}{*}{20} & $\mathrm{M}$ & 3,82 & 2,98 & 3,37 \\
\cline { 2 - 5 } & $\mathrm{SD}$ & 0,850 & 0,490 & 1,080 \\
\hline \multirow{2}{*}{50} & $\mathrm{M}$ & 2,9 & 2,61 & 3,57 \\
\cline { 2 - 5 } & $\mathrm{SD}$ & 0,102 & 0,582 & 1,970 \\
\hline \multirow{2}{*}{200} & $\mathrm{M}$ & $1,83^{*}$ & 2,23 & 3,50 \\
\cline { 2 - 5 } & $\mathrm{SD}$ & 0,089 & 0,874 & 0,718 \\
\hline \multirow{2}{*}{500} & $\mathrm{M}$ & $1,74^{*}$ & $1,83^{*}$ & $1,87^{*}$ \\
\cline { 2 - 5 } & $\mathrm{SD}$ & 0,045 & 0,246 & 0,650 \\
\hline
\end{tabular}

$*-p<0,05$

months of exposure, indicating a relief of 7 HOC effect assessed with the particular end point. Thus, despite of no statistically significant changes of BGL were found at dose level $50 \mathrm{mg} / \mathrm{kg}$, BMD analysis revealed this dose as toxicologically meaningfull after 1 , and 2 months of exposure.

Alongside this, we assessed BMD-BMDL distance, reflecting the BMD uncertainty. As it can be seen from Table 3, BMD estimates for STL increase at all three time points were similar, whereas for BGL decrease BMD values grew with the time of exposure. In our opinion, coupled with the observed temporal BMDL rise, it may be additional evidence of a lessening of bio-system response defined by BGL decrease, although an influence of other factors (e.g. quality of study, not enough fitting to modelling criteria of the data at 3 months time point) can not be excluded.
Table 3

Blood glucose level data set $(M, S D, n=5)$

\begin{tabular}{|c|c|c|c|c|}
\hline \multirow{2}{*}{ End point } & $\begin{array}{c}\text { Time of } \\
\text { expo- } \\
\text { sure, } \\
\text { month }\end{array}$ & $\begin{array}{c}\text { BMD, } \\
\mathbf{m g} / \mathbf{k g}\end{array}$ & $\begin{array}{c}\text { BMDL, } \\
\mathbf{m g} / \mathbf{k g}\end{array}$ & $\begin{array}{c}\text { BMD- } \\
\text { BMDL, } \\
\mathbf{m g} / \mathbf{k g}\end{array}$ \\
\hline \multirow{3}{*}{$\begin{array}{c}\text { STL } \\
\text { rise }\end{array}$} & 1 & 47,7 & 21,5 & 26,2 \\
\cline { 2 - 5 } & 2 & 48,5 & 20,5 & 28,0 \\
\cline { 2 - 5 } & 3 & 45,7 & 21,6 & 24,1 \\
\hline \multirow{3}{*}{$\begin{array}{c}\text { BGL } \\
\text { decrease }\end{array}$} & 2 & 47,8 & 23,9 & 23,9 \\
\cline { 2 - 5 } & 3 & 486,0 & 206,6 & 279,4 \\
\hline
\end{tabular}

\section{Conclusions}

1. BMD method derived estimates defined in 1,2, 3 month of exposure of 7-HOC in the subchronic study in rats provide more powerful assessment of two considered endpoints (STL increase and BGL decrease). When no change of STL in 1 month of exposure at dose 50 $\mathrm{mg} / \mathrm{kg}$ was found by means of conventional statistic, BMDL estimate at this dose-timepoint was $21,5 \mathrm{mg} / \mathrm{kg}$. NOAEL for BGL decrease was defined as $50 \mathrm{mg} / \mathrm{kg}$ in 1 month of exposure, and $200 \mathrm{mg} / \mathrm{kg}$ in 2, and in 3 months of exposure, whereas BMDL estimates were 23,$9 ; 21,0 \mathrm{mg} / \mathrm{kg}$ in 1,2 months respectively, and $206,0 \mathrm{mg} / \mathrm{kg}$ in 3 months.

2. The obtained data gave an evidence of no aggravation of toxicological/biological response within the time of 7-HOC exposure. Moreover, the defined for BGL decrease BMD method derived estimates increasing within the time of exposure reflect normalization of homeostasis within the time of 7-HOC subchronic exposure. Obtained information can be useful for more accurate prediction of NOAEL of chronic 7-HOC exposure.
1. Crump, K. (1984). A new method for determining allowable daily intakes. Fundamental and Applied Toxicology, 4, 854-871.

2. Gaylor, D.W., and Slikker, W. (2004). Role of the standard deviation in the estimation of benchmark doses with continuous data. Risk Analysis, 6, 1683-1687.

3. Principles and Methods of Toxicology (2007). Fifth Edition, edited by A. W.Hayes. CRC Press, 2296 p.

4. Slob W. and Setzer R.W. (2014). Shape and steepness of toxicological dose-response relationships of continuous endpoints. Critical Reviews in Toxicology, 44, 270-297

5. US EPA. Benchmark dose technical guidance. (EPA/100/R-12/001. Risk Assessment Forum, Washington, DC). Available online : http:// www.epa.gov/raf/publications/pdfsbenchmark_dose_gui dance.pdf

6. Ritschel, W.A., Hoffmann, K.A. (1981). A pilot study on the bioavailability of coumarin and 7-hydroxycoumarin 
upon peroral administration of coumarin in a sustainedrelease dosage form. The Journal Clinical Pharmacology, Jul; 21(7), 294-300

7. B. Ramesh, K.V. Pugalendi (2006). Antihyperglycemic effect of umbelliferone in streptozotocin-diabetic rats. Journal of Medicinal Food, 9(4), 562-566.

8. Ramesh, B., Pugalendi, K. V. (2006). Impact of umbelliferone (7-hydroxycoumarin) on hepatic marker enzymes in streptozotocin diabetic rats. Indian Journal of Pharmacology, 38, 209-210.

9. Rauf, A., Khan, R., Khan, H., Pervez, S., Pirzada, A.S. (2014). In vivo antinociceptive and anti-inflammatory activities of umbelliferone isolated from Potentillae vestita. Natural Product Research, 28(17), 1371-1374.

10. Muthu R., Selvaraj N., Vaiyapuri M. (2016). Anti-inflammatory and proapoptotic effects of umbelliferone in colon carcinogenesis. Human \& Experimental Toxicology, Oct; 35(10), 1041-1054.

11. Mohamed, M.R., Emam, M., Hassan, N.S., Mogadem, A.I. (2014). Umbelliferone and daphnetin ameliorate carbon tetrachloride-induced hepatotoxicity in rats via nuclear factor erythroid 2-related factor 2-mediated heme oxygenase-1 expression. Environmental Toxicology and Pharmacology, Sep; 38 (2), 531-541.

12. Kandil, S., Westwell, A.D., McGuigan, C. (2016). 7Substituted umbelliferone derivatives as androgen receptor antagonists for the potential treatment of prostate and breast cancer. Bioorganic \& Medicinal Chemistry Letters, Apr; 26(8), 2000-2004.

13. Zinovieva M., Zhminko P., Filinska O., Kharchuk I., Yablonska C., Karpezo N., Linchak O. (2014). Mode and peculiarities of toxic action of 7-hydroxicoumarin in organism under condition of long-lasting exposure. Modern problems of toxicology, food and chemical safety, 3/4(66/67), 63-71.

14. Jung-Min Lee, Min-Ah Lee, Hyeon-Nam Do, Yun-Ik Song, Re-Ji-Na Bae, Hye-Yeong Lee, Sun Hee Park, Jin Seok Kang, Jong-koo Kang (2012). Historical control data from 13-week repeated toxicity studies in Crj:CD (SD) rats. Laboratory Animal Research, 28(2), 115-121.

\section{ЗАСТОСУВАННЯ «БЕНЧМАРК-ДОЗА» МЕТОДОЛОГЇ̈ ДЛЯ ОЦІНКИ ЗАЛЕЖНОСТІ ЕФЕКТУ ВІД ДОЗИ ТА ЧАСУ ЕКСПОЗИЦӤ 7-ГІДРОКСИКУМАРИНУ ЗА 90-ДЕННОГО ВПЛИВУ НА САМОК ЩУРІВ М.Л. Зінов'єва, П.Г.Жмінько, М.Г.Проданчук \\ ДП «Науковий центр превентивної токсикології, харчової та хімічної безпеки імені академіка Л.І.Медведя МОЗ України», м. Київ, Україна}

PЕЗЮМЕ. Застосування «бенчмарк-доза» (БМД) підходу до існуючих пакетів токсикологічних даних, отриманих в ході експериментальних досліджень на тваринах і проаналізованих із застосуванням NOAEL/LOAEL методології, дозволяє реалізувати більш кількісно визначену, науково обгрунтовану оцінку ризику хімічного впливу на організм. У попередніх дослідженнях токсичності 7-гідроксикумарину (7-ГОК) за впливу протягом 3-х місяців на організм шурів було визначено порушення обміну ліпідів та вуглеводів (зниження рівня глюкози в крові (РГК) та підвищення рівня тригліцеридів у сироватці (PTC) крові), кваліфіковані як біологічно релевантні параметри для встановлення NOEL (20 мг/кг).

Мета роботи. Порівняльний аналіз залежсності ефекту 7-ГОК від дози та часу експозиції за даними РТС та РГК з опублікованого пакету даних про субхронічну токсичність 7-ГОК для щурів з використанням «бенчмарк-доза» (БМД) та NOAEL/LOAEL методологій.

Матеріали і методи. У роботі використано пакет непереривних даних щодо РТС та РГК у шурів самок за результатами проведеного субхронічного дослідження 7-ГОК. Аналіз даних виконано засобами програмного забезпечення ВMDS 2.6.0.1. Встановлений рівень відповіді- $10 \%$.

Результати. Визначено, що модель Хілла релевантно відображає залежність змін РТС та РГК від дози 7-ГОК. Значення БМД, розраховані за змінами РТС були подібними (46-49 мг/кг) через 1, 2 та 3 місяці впливу. Аналогічна залежність була виявлена для нижніх границь довірчих інтервалів бенчмарк-доз (БМДН), що знаходились у межах 21-22 мг/кг для всіх досліджених часових точок, тоді як NOEL для даної кінцевої точки був визначений на рівні 50, 20 та 20 мг/кг через 1, 2 та 3 місяиі відповідно.

БМД, визначені за зниженням РГК, зростали залежно від часу експозиції, становлячи 48, 93, 486 мг/кг через 1, 2 та 3 місяці відповідно. Визначені відповідні БМДН були 24, 21, 207 мг/кг через 1, 2 та 3 місяці відповідно, тоді як NOEL складав 50, 200, 200 мг/кг у відповідні часові точки.

Висновки. БМД метод є більш потужним інструментом статистичного аналізу залежності ефектів 7-ГОК від дози, порівняно з традиційним підходом. Зміни БМД та їі похідних свідчать про те, що не відбувається агравації з часом ефекmу 7-ГОК, визначеного за змінами РТС та РГК.

Ключові слова: «бенчмарк-доза» підхід, 7-гідроксикумарин, субхронічна токсичність.

\section{ПРИМЕНЕНИЕ «БЕНЧМАРК-ДОЗА» МЕТОДОЛОГИИ ДЛЯ ОЦЕНКИ ЗАВИСИМОСТИ ЭФФЕКТА ОТ ДОЗЫ И ВРЕМЕНИ ЭКСПОЗИЦИИ 7-ГИДРОКСИКУМАРИНА ПРИ 90-ДНЕВНОМ ВОЗДЕЙСТВИИ НА САМОК КРЫС}

М.Л. Зиновьева, П.Г.Жминько, Н.Г.Проданчук

ДП «Научный центр превентивной токсикологии, пищевой и химической безопасности имени академика Л.И.Медведя МЗ Украини», г. Киев, Украина

PЕЗЮМЕ . Применение «бенчмарк-доза» (БМД) подхода к существующим пакетам токсикологических данных, полученных в ходе экспериментальных исследований на животных и проанализированных с применением NOAEL/LOAEL методологии, позволяет провести в большей степени количественно определенную и научно обоснованную оценку риска химиче- 
ского воздействия на организм. В предыдущих исследованиях токсичности 7-гидроксикумарина (7-ГОК) при воздействии в течение 3-х месяцев на организм крыс были выявлены нарушения обмена липидов и углеводов (снижение уровня глюкозы 8 крови (УГК) и повышение уровня триглицеридов в сыворотке (УТС) крови), квалифицированные как биологически релевантные параметры для установления NOEL (20 мг/кг).

Цель работы. Сравнительный анализ зависимости эффекта 7-ГОК от дозы и времени экспозиции по данным об изменениях УТС и УГК из опубликованного пакета данных о субхронической токсичности 7-ГОК для крыс с использованием БМД и NOAEL/LOAEL методологий.

Материалы и методы. В работе использован пакет непрерывных данных, характеризующих УТС и УГК у крыс самок по результатам проведенного субхронического исследования 7-ГОК. Анализ данных выполнен средствами программного обеспечения BMDS 2.6.0.1. Установленный уровень ответа составлял $10 \%$.

Результаты. Определено, что модель Хилла релевантно отражает зависимость изменений УТС и УГК от дозы 7-ГОК. Значения БМД, рассчитанные по изменениям УТС, были сходными (46-49 мг/кг) через 1, 2 и 3 месяиа воздействия. Аналогичная зависимость была обнаружена для нижних границ доверительных интервалов бенчмарк-доз (БМДН), которые находились в пределах 21-22 мг/кг для всех исследованных временных промежутков, тогда как NOEL для данной конечной точки составлял 50, 20 и 20 мг/кг через 1, 2 и 3 месяца соответственно. БМД, определенные по снижению УГК, возрастали с увеличением времени экспозиции, составляя 48, 93, 486 мг/кг через 1, 2 и 3 месяца соответственно. Установленные БМДН составляли 24, 21, 207 мг/кг через 1, 2 и 3 месяца соответственно, тогда как NOEL составлял 50, 200, 200 мг/кг в указанные временные точки.

Выводы. БМД метод является более мощным инструментом статистического анализа зависимости эффектов 7-ГОК от дозы по сравнению с традиционным подходом. Наблюдаемые изменения БМД и ее производных свидетельствуют, что не происходит аггравации со временем эффекта 7-ГОК, определенного по изменениями УТС и УГК.

Ключевые слова: «бенчмарк-доза» подход, 7-гидроксикумарин, субхроническая токсичность

Надійшла до редакції 10.01.2018 p. 